\title{
The fertilizing capacity of epididymal spermatozoa in relation to age, body weight and the onset of sexual maturity in the golden hamster
}

\author{
C. M. Lubicz-Nawrocki and M. C. Chang \\ Worcester Foundation for Experimental Biology, Shrewsbury, Massachusetts 01545, U.S.A.
}

\begin{abstract}
Summary. Experiments with prepubertal hamsters were undertaken to determine if the appearance of spermatozoa with fertilizing capacity in the cauda epididymidis is related to age and/or body weight and whether the development of sperm function coincides with complete maturation of the mating behaviour pattern. At Week 6 after birth, intrauterine insemination of comparable numbers of spermatozoa showed that fertilizing capacity was related to body weight and not to age or seminal vesicular fructose concentration. In contrast to the low fertilization rate produced by spermatozoa from males weighing $80 \mathrm{~g}$ at Week 6 after birth, spermatozoa from $80-\mathrm{g}$ males at Week 7 showed normal fertilizing capacity. Only $50 \%$ of 7 -week-old males weighing $100-110 \mathrm{~g}$ produced fertile matings whereas all matings were fertile with males weighing $135 \mathrm{~g}$ and with males weighing 100 to $110 \mathrm{~g}$ that had received 7 consecutive daily injections of $50 \mu \mathrm{g}$ testosterone beginning at Week 6 after birth. Comparison of sperm numbers in the cauda epididymidis and ductus deferens after mating at Week 7 showed that males which produced sterile matings were unable to terminate intromission with normal ejaculation of spermatozoa.
\end{abstract}

\section{Introduction}

The term sexual maturity is often used to include events which precede the ability of male animals to reproduce, e.g. the presence of spermatozoa in the testis, the onset of sexual behaviour and changes in gonadotrophin secretion. Clegg (1960) concluded that age in rats is a good indicator of sexual maturity, but in guinea-pigs body weight was more closely correlated with the first appearance of spermatozoa in the ejaculate than was age (Freund, 1960). Because of this species difference and some preliminary findings in hamsters, the present study was undertaken to determine if the appearance of spermatozoa with fertilizing capacity in the cauda epididymidis is related to age and/or body weight, and whether this coincides with the complete development of the mating behaviour pattern, i.e. the ability to intromit and to ejaculate during copulation.

\section{Materials and Methods}

Male and female hamsters were maintained under controlled conditions of temperature and light. Immature males were purchased about 10 days before use and fed a standard diet supplemented with green vegetables three times per week.

Throughout the study, the total number of spermatozoa in the cauda epididymidis and ductus deferens was determined as follows. Both caudae were macerated with fine scissors in 1-3 ml Hanks' solution; each ductus deferens was flushed with $0.3 \mathrm{ml}$ Hanks' solution and the flushings were added to the sperm suspension from the caudae. After thorough shaking in a test tube and sedimentation of the heavier matter for $1 \mathrm{~min}, 0.01 \mathrm{ml}$ of the sperm suspension was diluted to 1 or $10 \mathrm{ml} \mathrm{with} 10 \%$ formalin. The total number of spermatozoa in the cauda epididymidis and ductus deferens from both sides was estimated from the mean value of haemocytometer counts of three samples from the sperm suspension. 
To test fertilizing capacity of spermatozoa from the cauda epididymidis, a sperm suspension (one from each male) was prepared by macerating both caudae in $0.5-2.5 \mathrm{ml}$ Hanks' solution. The sperm suspensions were diluted when necessary so that comparable numbers of spermatozoa could be artificially inseminated. A sperm suspension $(0.2 \mathrm{ml})$ was injected into both uterine horns of an oestrous female anaesthetized with sodium pentobarbitone $(60 \mathrm{mg} / \mathrm{kg}$, i.p.). Females were killed approximately $48 \mathrm{hr}$ after artificial insemination, the eggs were flushed from the oviducts with Hanks' solution, mounted in toto and examined under a phase-contrast microscope for evidence of fertilization, i.e. the presence of a spermatozoon in the vitellus of a cleaved egg.

In those experiments in which tests were performed to examine mating behaviour and reproductive capacity, males were paired with oestrous females for $45 \mathrm{~min}$. Each male was scored for the number of intromissions and a vaginal smear from his partner was examined to see whether intromission was terminated by ejaculation of spermatozoa. Males were killed immediately after mating for total sperm counts. The females were killed $48 \mathrm{hr}$ after insemination to determine whether fertilization had occurred and the number of females in each group in which all the eggs were fertilized.

For the estimation of fructose, seminal vesicles from males in the different groups were thoroughly blotted on filter paper to remove the secretion and stored at $-20^{\circ} \mathrm{C}$. Both lobes were weighed and fructose was assayed in one lobe of each gland using a slight modification (Lubicz-Nawrocki \& Glover, 1973) of the method originally described by Lindner \& Mann (1960). The other lobe was dried to constant weight at $150^{\circ} \mathrm{C}$ to determine the percentage of dry matter.

Differences between means were analysed with Student's $t$ test and evaluated as statistically significant at the $P<0.05$ level.

\section{Results}

\section{Experiment 1}

Groups of males weighing 70-100 g were killed 5, 6 or 7 weeks after birth to determine when spermatozoa first appear in the cauda epididymidis and whether testicular weight, the weight of the cauda epididymidis and its sperm content are related to chronological age and/or body weight. Table 1 shows that testicular weight increases with body weight but the increments were not significant.

The mean total weight of the right and left cauda epididymidis did not vary significantly with body weight at Week 5 when sperm content was negligible but was significantly greater at Week 6 in males weighing $100 \mathrm{~g}$ compared with those weighing $70 \mathrm{~g}(P<0.005)$; this difference in weight was accompanied by a significant increase in the mean total sperm content of the cauda epididymidis on both sides.

Table 1. Mean \pm S.E.M. weights of the testis and cauda epididymidis, sperm content of the cauda and the concentration of fructose in the seminal vesicles in hamsters of different ages and body weights

\begin{tabular}{|c|c|c|c|c|c|c|}
\hline & \multirow{2}{*}{$\begin{array}{c}\text { Age } \\
\text { (weeks) }\end{array}$} & \multicolumn{5}{|c|}{ Body weight (g) } \\
\hline & & 70 & 80 & 90 & 100 & 110 \\
\hline Mean of both testes $(\mathrm{g})$ & $\begin{array}{l}5 \\
6 \\
7\end{array}$ & $\begin{array}{l}1 \cdot 21 \pm 0.15 \\
1 \cdot 31 \pm 0.04 \\
2 \cdot 11 \pm 0 \cdot 10\end{array}$ & $\begin{array}{l}1.37 \pm 0.01 \\
2.04 \pm 0.21 \\
2.21 \pm 0.20\end{array}$ & $\begin{array}{r}1.44 \pm 0.09 \\
2 \pm 0.07 \\
2.32 \pm 0.26\end{array}$ & $\begin{array}{l}1.94 \pm 0.65 \\
2.33 \pm 0.19 \\
2.65 \pm 0.06\end{array}$ & $\begin{array}{c}- \\
2.30 \pm 0.08 \\
2.54 \pm 0.19\end{array}$ \\
\hline $\begin{array}{l}\text { Mean total weight of } \\
\text { right and left cauda } \\
\text { epididymidis (g) }\end{array}$ & $\begin{array}{l}5 \\
6 \\
7\end{array}$ & $\begin{array}{l}0.05 \pm 0 \\
0.08 \pm 0.02 \\
0.16 \pm 0.02\end{array}$ & $\begin{array}{l}0.05 \pm 0 \\
0.08 \pm 0.01 \\
0.22 \pm 0.04\end{array}$ & $\begin{array}{l}0.08 \pm 0.02 \\
0.09 \pm 0 \\
0.15 \pm 0.02\end{array}$ & $\begin{array}{l}0.06 \pm 0 \\
0.12 \pm 0.01 \\
0.21 \pm 0.01\end{array}$ & $\begin{array}{c}-\overline{0} \\
0.19 \pm 0.02 \\
0.22 \pm 0.01\end{array}$ \\
\hline $\begin{array}{l}\text { Mean total no. of } \\
\text { sperm. in right and } \\
\text { left cauda } \\
\text { epididymidis }\left(\times 10^{6}\right)\end{array}$ & $\begin{array}{l}5 \\
6 \\
7\end{array}$ & $\begin{array}{c}0 \\
101 \cdot 6 \pm 26 \cdot 9 \\
102 \cdot 6 \pm 15 \cdot 6\end{array}$ & $\begin{array}{c}0 \\
113 \cdot 7 \pm 16 \cdot 8 \\
118 \cdot 1 \pm 16 \cdot 9\end{array}$ & $\begin{array}{c}9 \cdot 6 \pm 1 \cdot 9 \\
70 \cdot 3 \pm 17 \cdot 6 \\
104 \cdot 6 \pm 12 \cdot 5\end{array}$ & $\begin{array}{c}15 \cdot 2 \pm 2 \cdot 1 \\
156 \cdot 2 \pm 14 \\
280 \pm 30 \cdot 2\end{array}$ & $\begin{array}{c}- \\
180 \cdot 5 \pm 52 \cdot 7 \\
234 \cdot 2 \pm 12 \cdot 1\end{array}$ \\
\hline $\begin{array}{l}\text { Mean seminal vesicle } \\
\text { fructose }(\mathrm{mg} / 100 \mathrm{~g} \\
\text { dry weight) }\end{array}$ & $\begin{array}{l}5 \\
6 \\
7\end{array}$ & $\begin{array}{l}4.91 \pm 0.35 \\
5.46 \pm 0.77 \\
4.01 \pm 0.62\end{array}$ & $\begin{array}{l}5 \cdot 01 \pm 1 \cdot 16 \\
4 \cdot 38 \pm 0 \cdot 81 \\
6.44 \pm 1 \cdot 23\end{array}$ & $\begin{array}{l}3.64 \pm 0.63 \\
4.76 \pm 1.01 \\
4.38 \pm 0.83\end{array}$ & $\begin{array}{l}3.39 \pm 0.22 \\
4.89 \pm 0.58 \\
3.92 \pm 0.46\end{array}$ & $\begin{array}{l}5.22 \pm 0.60 \\
3.21 \pm 0.23\end{array}$ \\
\hline
\end{tabular}




\section{Experiment II}

To test whether fertilizing capacity of spermatozoa at Week 6 after birth (when significant numbers of spermatozoa first appear in the cauda epididymidis, Table 1) is related to chronological age or to body weight, males were killed and their spermatozoa used for artificial insemination as described above. The results in Table 2 show that the fertilizing capacity of spermatozoa at Week 6 after birth was related to body weight.

Table 2. Fertilizing capacity of spermatozoa from the cauda epididymidis of 6-week-old hamsters in relation to body weight (mean \pm S.E.M.)

\begin{tabular}{|c|c|c|c|c|c|c|}
\hline $\begin{array}{c}\text { Body } \\
\text { weight (g) }\end{array}$ & $\begin{array}{l}\text { Seminal vesicle } \\
\text { fructose }(\mathrm{mg} / 100 \mathrm{~g} \\
\text { dry weight) }\end{array}$ & $\begin{array}{c}\text { No. of } \\
\text { females } \\
\text { inseminated }\end{array}$ & $\begin{array}{c}\text { No. of sperm. } \\
\text { inseminated } \times 10^{6}\end{array}$ & $\begin{array}{c}\text { Total no. } \\
\text { of eggs } \\
\text { recovered } \dagger\end{array}$ & $\begin{array}{l}\text { Fertilization } \\
\text { rate }\end{array}$ & $\begin{array}{c}\text { No. of } \\
\text { females } \\
\text { with all } \\
\text { eggs } \\
\text { fertilized }\end{array}$ \\
\hline 80 & $4.86 \pm 0.81$ & 10 & $6 \cdot 5 \pm 3 \cdot 4$ & 115 & 33.04 & 1 \\
\hline 90 & $3.91 \pm 1.22$ & 10 & $7 \cdot 3 \pm 2 \cdot 1$ & 113 & $29 \cdot 2$ & 2 \\
\hline 100 & $4.42 \pm 0.91$ & 10 & $8 \cdot 8 \pm 2 \cdot 2$ & 102 & $78 \cdot 4$ & 6 \\
\hline 110 & $4.48 \pm 1.04$ & 10 & $7 \cdot 6 \pm 2 \cdot 1$ & 112 & 100 & 10 \\
\hline
\end{tabular}

* With spermatozoa from the cauda epididymidis; one female/male.

$\uparrow 48 \mathrm{hr}$ after artificial insemination.

$\ddagger$ As the \% of eggs recovered.

\section{Experiment III}

Tests of fertilizing capacity of spermatozoa from males weighing $80 \mathrm{~g}$ at Week 7 after birth showed that all of the eggs were fertilized in each female in contrast to the low fertilization rate following insemination of spermatozoa from 6-week-old males of the same body weight (Exp. II). To show whether the development of fertilizing capacity coincides with the complete maturation of sexual behaviour, however, mating tests were conducted to examine the ability of males to ejaculate during copulation at Week 7 after birth. Table 3 shows that $50 \%$ of the matings of the 10 males weighing $100-110 \mathrm{~g}$ (Group 1) were infertile even though the mean number of intromissions was comparable to that recorded for the fertile males. The total number of spermatozoa in the fertile males was significantly lower $(P<0.005)$ than in the five infertile males and in the unmated animals (Group 2, Table 3).

Table 3. Age and body weight as determinants of sexual maturity in 7 -week-old male hamsters (mean \pm S.E.M.)

\begin{tabular}{|c|c|c|c|c|c|c|c|c|}
\hline $\begin{array}{c}\text { Group } \\
\text { (no. of males) }\end{array}$ & $\begin{array}{c}\text { Mean body } \\
\text { wt (g) }\end{array}$ & $\begin{array}{c}\text { Seminal } \\
\text { vesicle } \\
\text { fructose } \\
\text { (mg/100 g } \\
\text { dry weight) }\end{array}$ & $\begin{array}{l}\text { No. of } \\
\text { females } \\
\text { mated* }\end{array}$ & $\begin{array}{l}\text { No. of } \\
\text { intro- } \\
\text { missions }\end{array}$ & $\begin{array}{l}\text { Total no. of } \\
\text { sperm. in both } \\
\text { caudae and ductus } \\
\text { deferentes after } \\
\text { mating }\left(\times 10^{6}\right)\end{array}$ & $\begin{array}{l}\text { Total no. } \\
\text { of eggs } \\
\text { recovered } t\end{array}$ & $\begin{array}{c}\text { Fertil- } \\
\text { ization } \\
\text { rate }\end{array}$ & $\begin{array}{c}\text { No. of } \\
\text { females } \\
\text { with all } \\
\text { eggs } \\
\text { fertilized }\end{array}$ \\
\hline \multicolumn{9}{|l|}{ Group 1} \\
\hline Mated (5) & $107 \pm 2$ & $3.42 \pm 0.91$ & 5 & $34.6 \pm 1.9$ & $288.7 \pm 42.6$ & 63 & 100 & 5 \\
\hline Mated (5) & $108 \pm 3$ & $3.06 \pm 0.94$ & 5 & $32 \pm 3$ & $460 \cdot 8 \pm 32.4$ & 68 & $7 \cdot 3$ & 0 \\
\hline \multicolumn{9}{|l|}{ Group 2} \\
\hline $\begin{array}{l}\text { Unmated (10) } \\
\text { Group } 3\end{array}$ & $96 \cdot 6 \pm 2 \cdot 5$ & $3.59 \pm 0.72$ & 0 & - & $428 \pm 45 \cdot 9$ & - & - & - \\
\hline Mated (10) & $135 \pm 1 \cdot 6$ & $4.41 \pm 1 \cdot 11$ & 10 & $35.6 \pm 4.7$ & $266 \cdot 2 \pm 19 \cdot 4$ & 120 & 100 & 10 \\
\hline Unmated (5) & $132 \pm 1 \cdot 8$ & $3.89 \pm 0.91$ & 5 & - & $484 \pm 24.9$ & 一 & 一 & 一 \\
\hline
\end{tabular}

* With spermatozoa from the cauda epididymidis; one female/male.

$\dagger$ From the total number of mated females $48 \mathrm{hr}$ after insemination.

$\ddagger$ As $\%$ of eggs recovered. 
To test whether the ability to ejaculate spermatozoa is related to body weight at Week 7 after birth, 10 out of 15 males (Group 3, Table 3) weighing approximately $135 \mathrm{~g}$ were mated. All of the eggs were fertilized in each mated female and ejaculation ability was similar to that of the sexually mature males in Group I as judged by the significant decrease $(P<0.001)$ in the total number of spermatozoa compared with that in the unmated control males (Group 3, Table 3).

\section{Experiment IV}

During the course of this study, 10 males were observed to mate at Week 7 after birth but no spermatozoa were detected in the vaginal smears and the matings were infertile. As an extension of Exp. III these males were tested again 1 week later to ascertain whether development of the ability to terminate intromission with ejaculation of spermatozoa is delayed in some males. The results showed that (i) the mean number of intromissions was comparable to that at Week 7 after birth $(36.7 \pm 5 \cdot 5$ and $37 \cdot 6 \pm 4 \cdot 5$, respectively); (ii) all the eggs were fertilized in each mated female; and (iii) the mean number of spermatozoa in the cauda epididymidis and ductus deferens on both sides was $275 \cdot 1 \times 10^{6} \pm 84 \cdot 3$ compared with $559 \cdot 5 \times 10^{6} \pm 45 \cdot 2$ in unmated controls.

\section{Experiment $V$}

Males weighing 100-110 g were given 7 consecutive daily injections of $50 \mu \mathrm{g}$ testosterone (Sigma Chemical Co.) beginning at Week 6 after birth. Testosterone was injected s.c. in $0 \cdot 1 \mathrm{ml}$ sesame oil $/ 100 \mathrm{~g}$ body wt while control animals received $0 \cdot 1 \mathrm{ml}$ sesame oil only. Table 4 shows that in contrast to the sterile matings of the oil-injected control males, all matings of the testosterone-treated males were fertile. The difference in fertility between the two groups of males was associated with significantly lower numbers of spermatozoa remaining in the cauda epididymidis and ductus deferens in the testosterone-treated males $(P<0 \cdot 001)$.

Table 4. Fertility of 7-week-old male hamsters after treatment with testosterone (mean \pm S.E.M.)

\begin{tabular}{|c|c|c|c|c|c|c|c|}
\hline $\begin{array}{l}\text { Treatment } \\
\text { (10 males/ } \\
\text { group) }\end{array}$ & $\begin{array}{c}\text { Seminal } \\
\text { vesicle } \\
\text { fructose } \\
\text { (mg/ } 100 \mathrm{~g} \\
\text { dry weight) }\end{array}$ & $\begin{array}{l}\text { No. of } \\
\text { females } \\
\text { mated }\end{array}$ & $\begin{array}{l}\text { No. of } \\
\text { intromissions }\end{array}$ & $\begin{array}{l}\text { No. of sperm. in } \\
\text { both caudae and ductus } \\
\text { deferentes }\left(\times 10^{6}\right)\end{array}$ & $\begin{array}{l}\text { Total no. } \\
\text { of eggs } \\
\text { recovered* }\end{array}$ & $\begin{array}{l}\text { Fertili- } \\
\text { zation } \\
\text { rate } \neq\end{array}$ & $\begin{array}{c}\text { No. of } \\
\text { females } \\
\text { with all } \\
\text { eggs } \\
\text { fertilized }\end{array}$ \\
\hline Oil (control) & $4 \cdot 76 \pm 1 \cdot 01$ & 10 & $32.5 \pm 3.7$ & $543 \cdot 6 \pm 51 \cdot 3$ & 110 & $45 \cdot 4$ & 5 \\
\hline $\begin{array}{l}\text { Testosterone } \\
(50 \mu \mathrm{g} / \text { day }) \\
\text { for } 7 \text { days })\end{array}$ & $4.93 \pm 0.23$ & 10 & $35 \cdot 6 \pm 4 \cdot 2$ & $376.4 \pm 11.6 \dagger$ & 116 & 100 & 10 \\
\hline
\end{tabular}

* From total no. of mated females.

+ Significantly lower than control; $P<0.001$.

$\ddagger$ As $\%$ of eggs recovered.

\section{Fructose changes}

The mean concentrations of fructose in the seminal vesicles of 5-, 6- and 7-week-old males were comparable and not related to body weight (Table 1), as also shown by values at Week 7 after birth in males weighing approximately $135 \mathrm{~g}$ (Group 3, Table 3) in which the mean fructose level was similar to that found in the sexually mature and immature males weighing 100-110 g (Group 1, Table 3). Treatment with testosterone during Week 6 increased the mean concentration of seminal vesicle fructose but not significantly so (Table 4). 


\section{Discussion}

This study shows that testicular weight increases with body weight in 5-, 6- and 7-week-old hamsters but that significant numbers of spermatozoa are not found in the cauda epididymidis until Week 6 after birth. This finding differs from those for the rat (Clegg, 1960; Chang, Niwa \& Hunt, 1975), guinea-pig (Webster \& Young, 1951) and rabbit (Chang et al., 1975) in which spermatozoa first appear in the cauda at Weeks 9, 11 and 13-15 after birth, respectively. Chang et al. (1975) reported that in 16- to 23-week-old New Zealand White rabbits there was no difference in the fertilizing capacity of caudal spermatozoa as long as sufficient numbers were available for insemination. In the present study, however, the fertilizing capacity of spermatozoa from prepubertal hamsters was related to body weight rather than to chronological age since all the eggs were fertilized by spermatozoa from males weighing $110 \mathrm{~g}$ at Week 6 after birth in contrast to the low fertilization rate after insemination of comparable numbers of spermatozoa from males weighing 80 and $90 \mathrm{~g}$. However, a higher proportion of epididymal spermatozoa had developed fertilizing capacity at Week 7 after birth in males weighing $80 \mathrm{~g}$ compared with those 6 weeks after birth since all the eggs were fertilized in each female.

Early observations on the copulatory behaviour of hamsters (Bond, 1945) showed that some males will copulate as early as 30 days after birth but fertile matings did not occur until the 7 th week. The present findings are consistent with the latter observation but although most of the 7-week-old males weighing about $110 \mathrm{~g}$ ejaculate spermatozoa during copulation, only $50 \%$ ejaculated sufficient spermatozoa for normal fertilization to occur. In male hamsters, as in rats (Clegg, 1960), sexual maturation is related to body weight since all matings with males weighing $135 \mathrm{~g}$ at Week 7 after birth were fertile, but chronological age also seems important because all of the males weighing between 100 and $110 \mathrm{~g}$ that did not impregnate females at Week 7 after birth did so 1 week later.

The failure of fertilization after copulation with 7-week-old males seems to have been due to abnormal ejaculation of spermatozoa. In this study, the relative sperm numbers in the cauda epididymidis and ductus deferens were used as an index of ejaculation ability because Chang \& Shaeffer (1957) showed that when sexually mature hamsters copulate they ejaculate approximately $45 \%$ of the total number of spermatozoa in the cauda epididymidis. Since significantly higher numbers of spermatozoa were consistently found in the cauda epididymidis and ductus deferens of 7 -week-old males that produced sterile matings compared with those males that were fertile, it is concluded that the difference in fertility was due to a delay in the maturation of ejaculation ability. This delay in the complete development of the sexual behaviour pattern was especially evident in the males that failed to ejaculate spermatozoa at Week 7 after birth but which produced fertile matings 1 week later. Similar observations were reported in prepubertal guinea-pigs in which intromission was not accompanied by ejaculation of spermatozoa during early matings (Webster \& Young, 1951). It seems, therefore, that development of the ability to ejaculate sufficient spermatozoa to effect $100 \%$ fertilization of eggs occurs later than the capacity to intromit and, as in the guinea-pig (Webster \& Young, 1951) and the rat (Clegg, 1960), the period of adolescent infertility in the hamster lasts about 7-14 days.

It is not clear why some hamsters ejaculate insufficient spermatozoa for fertilization of eggs at Week 7 after birth. All males that received $50 \mu \mathrm{g}$ testosterone daily for 1 week produced fertile matings, and thus it would seem that exogenous testosterone might increase circulating androgen levels sufficiently to differentially stimulate the development of ejaculation ability without producing an increase in the level of seminal vesicular fructose. The hormonal requirements for the functional development of the short adrenergic post-ganglionic neurons that innervate the smooth musculature of the cauda epididymidis and ductus deferens in a variety of species (Sjostrand, 1965) are not known, but androgen is probably involved because postnatal deprivation of testosterone in rats reduces the norepinephrine content of the ductus deferens before and after the time when sexual maturity normally occurs (Broberg, Nybell, Owman, Rosengren \& Sjoberg, 1974).

This study was supported by a grant from the Ford Foundation and a grant (HD 03472) from the NIH, U.S. Public Health Service. We thank Mrs E. Senior for typing assistance. 


\section{References}

BoND, C.R. (1945) The golden hamster (Cricetus auratus) care, breeding, and growth. Physiol. Zool. 18, 52-59.

Broberg, A., Nybell, G., OWman, Ch., Rosengren, E. \& SJoberg, N.-O. (1974) Consequence of neonatal androgenization and castration for future levels of norepinephrine transmitter in uterus and vas deferens of the rat. Neuroendocrinology 15, 308-312.

Chang, M.C. \& Shaeffer, D. (1957) Number of spermatozoa ejaculated at copulation, transported into the female tract, and present in the male tract of the golden hamster. $J$. Hered. 48, 107-109.

Chang, M.C., Niwa, K. \& Hunt, D.M. (1975) Fertilizing capacity of spermatozoa and fertilizable life of eggs from immature and mature rabbits and rats. In Aging Gametes, pp. 166-178. Ed. R. J. Blandau. Karger, Basel.

ClegG, E.J. (1960) The age at which male rats become fertile. J. Reprod. Fert. 1, 118-119.
Freund, M. (1960) Development of semen production in the guinea-pig. Fedn Proc. Fedn Am. Socs exp. Biol. 19, 371, Abstr.

LINDNER, H.R. \& MANN, T. (1960) Relationship between the content of androgenic steroids in the testes and the secretory activity of the seminal vesicles in the bull. $J$. Endocr. 21, 341-360.

Lubicz-NAwrockı, C.M. \& Glover, T.D. (1973) The influence of the testis on the survival of spermatozoa in the epididymis of the golden hamster, Mesocricetus auratus. J. Reprod. Fert. 34, 315-329.

Sjostrand, N.O. (1965) The adrenergic innervation of the vas deferens and the accessory male genital glands. Acta physiol. scand. 65, Suppl. 257, 182.

Webster, R.C. \& Young, W.C. (1951) Adolescent sterility in the male guinea-pig. Fert. Steril. 2, 175181.

Received 16 March 1976 